\title{
The Development of E-Learning Module Based on Project-Based Learning (PJBL) for Electric Motor Installation Course
}

\author{
Rusmanto $^{1^{*}}$, Kasman Rukun ${ }^{2}$
}

1,2 Department of Electrical Engineering, State University of Padang, Indonesia

\section{A R T I C L E I N F O \\ Article history: \\ Received 22 February \\ 2020 \\ Received in revised \\ Form 01 March 2020 \\ Accepted 18 April 2020 \\ Available online 30 May \\ 2020}

\section{Keywords:}

E-learning Modul, PjBl,

IML, Research and

Development

\begin{abstract}
A B S T R A C T
The purpose of this research was to develop an E-learning module that can help students learn independently and valid, practical, and effective. This study was the Research and Development (R\&D) research method with the 4D (four-D) development model. The research phase includes define (the defining stage), design (the design phase), develop (the development stage), and disseminate (the deployment stage). The instrument used in this study was a questionnaire used to measure validity and practicality. Meanwhile, to measure the effectiveness, it was using the test instrument in the form of multiple-choice questions. E-learning module was based on Project Based Learning. The results showed that the Elearning module was declared valid with a validity score was 91.50 based on the validation of three media validators and in terms of the validity of the material declared valid with the score was 91.50 from three teachers. E-learning modules stated to be very practical based on teacher and student responses. This showed that the E-learning module effectively used as one of the teaching materials in learning in improving student learning outcomes. Based on the findings of the study it can be recommended that the E-learning module was an alternative teaching material in learning that can be used in learning on electric motorization (IML) subjects.
\end{abstract}

\section{Introduction}

Development in the field of education is part of the government's program to educate the life of the nation, the state, and efforts to improve the quality of Indonesia's human resources. Education is also an effort to improve the standard of living of people who are dignified and cultured. In UU No. 20 Tahun 2003 stated that "the goal of Indonesian education is to educate the life of the nation and make the Indonesian people devoted to God Almighty, virtuous, intelligent and knowledgeable, having a good personality, healthy physically and spiritually, and being responsible to society, nation and state". From this statement, it can be understood that Indonesian education aims to form skilled, intelligent intellectual, physically, and mentally healthy human resources, and can be the successors to a superior nation.

Skills are mandatory requirements and the basis of superior quality human resources. Especially in the field of education, these skills are closely related to vocational education. Vocational education in Indonesia is a government program in educating people to have skills following the fields of expertise offered in vocational education to meet the needs in the business and industrial world (Menrisal et al., 2019). Vocational High School (SMK) as vocational education or vocational training is expected to be able to produce students to be qualified human resources in their fields and able to answer future challenges and be able to fill the business and industrial world, so in learning the right methods are needed or appropriate learning media so that students have expected skills or abilities.

However, based on observations made at SMKN 5 Batam, many students have not passed the KKM either from the knowledge score or skills. The observations result summarized in the evaluation data of student learning percentages. 
Table 1. Evaluation Results of Student Learning Presentation TITL Department, SMKN 5 Batam

\begin{tabular}{ccccc}
\hline \multirow{2}{*}{ Total Student } & \multicolumn{2}{c}{ Knowledge score } & \multicolumn{2}{c}{ Skill score } \\
& Complete & Not Complete & Complete & Not Complete \\
\hline 42 & 22 & 20 & 23 & 19 \\
Percentage & $52 \%$ & $48 \%$ & $55 \%$ & $45 \%$ \\
\hline & & & \multicolumn{2}{c}{ Source; Jurusan TITL, SMKN 5 Batam }
\end{tabular}

From table 1, it can be seen that many students have not passed the KKM either from the knowledge score or the score of skills. From these data, it can be seen that students who have not completed as much as $48 \%$ for knowledge and $45 \%$ for the score of skills. This can be a problem in the learning process. This is one of the teacher tasks to develop educational knowledge by preparing a learning media by following the learning objectives, easy to use by teachers and students, the availability of media that is easy to obtain.

The development of technology has become a potential for the progress of online learning implementation. Online learning can distribute information and provide interaction services wherever and whenever. Learning content is not limited to certain knowledge, so students can learn widely, knowledge and insights received more and increase effectiveness and efficiency in learning in higher education and in learning in vocational secondary education. improve the ability of students to use technology optimally. Through e-learning, learning becomes effective in delivering teaching material so that it can achieve learning objectives. Also, e-learning has become efficient in terms of time, cost, and energy. Flexible learning can be done anywhere and anytime without the limitations of space and time.

The development of learning technology and the availability of teaching materials allows teachers to no longer source of learning (teacher center) but rather the teacher plays a role as a facilitator. Learners can search for learning information through the internet, e-books, and the surrounding environment. The effectiveness of, efficient, and learning flexibility can be implemented with e-learning. According to Sutopo (2012: 143) "e-learning is a form of web-based learning that can be accessed from the internet. E-learning as an innovation in vocational education and training has the potential to change teachers' new ways of teaching. Here are the results of student learning in the 2018/2019 academic year before using learning media in the form of E-learning modules.

Modules are learning tools or material tools, procedures, and assessments made systematically and structured to achieve the competencies needed by an understanding of each student (Hasanah et al., 2018). In the end, students are encouraged to learn. Nasution (2009: 205) states that this module may be known as one of the structured learning activities to allow students to achieve several objectives that are specifically and formulated. Majid (2006) states that the module is a teaching material that aims to students can learn independently without the guidance of the teacher so that the module contains at least the basic components of the teaching materials mentioned. It makes students are required to study independently to increase learning motivation and learning outcomes.

From the data and information obtained during observation, it is necessary to use modules, which are selected by researchers as a specification of instructional media that can be used by students to streamline learning during the implementation of the learning process between teachers and students, which enables students to be able to learn independently. The e-learning module that will be developed is online-based (Fatkhurrokhman et al., 2017). Online is derived from the words on and line, on means life, the line means channel. So online is the state of the computer or mobile connected to the internet. So online is a term used by the device connected to the internet network. From the online understanding, the module developed is a module that can be accessed on a smartphone or computer connected to the internet network. So that in the process of using its modules can attract students to use as learning material (Sugiharni, 2018).

Project-based learning methods are commonly used to streamline and optimize the learning process. According to Patton (2012: 13), project-based learning is a learning activity carried out by designing, planning, implementing, and producing an output product that can become an invention. Evaluation of which student learning experiences developed in this PjBL model make projects that require students to, (1) solve real problems and issues that have an interest in others; (2) are actively involved in their learning and choose important things during the project; (3) show clearly that they have learned key concepts and skills. Projects provide opportunities for students to produce observable evidence that they have mastered strict curricular standards because they apply their learning and solve problems at hand. Projects and exhibitions also provide extensive evidence of work and learning processes taking place on 
their own (Addiin, 2014). The aim and focus of this research were to develop an E-learning module that can help students learn independently and valid, practical, and effective (Novianto \& Masykuri, 2018).

\section{Method}

This research type was R\&D (Research and Development) with the 4D (four-D) development model. Here is the picture of the flowchart steps of project-based learning (Project Based Learning).

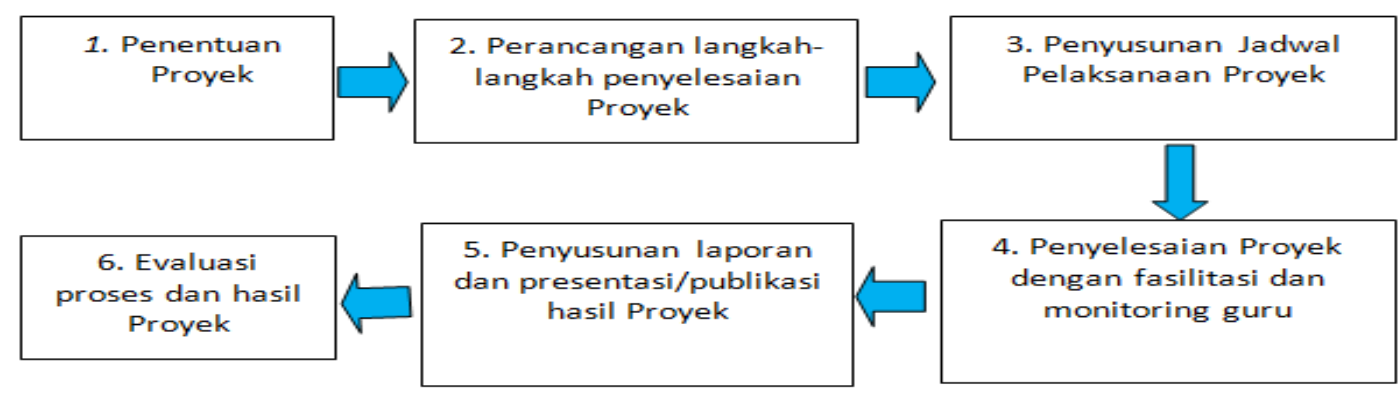

Figure 1. Project-based learning steps Adapted from KESER and Karagoca (2010)

E-learning module based on project-based learning was made through several stages, analyzing problems and potential problems, data collection, product design, design validation, design revision, product testing, product revision. If the product trial results meet the proper requirements, they will be published.

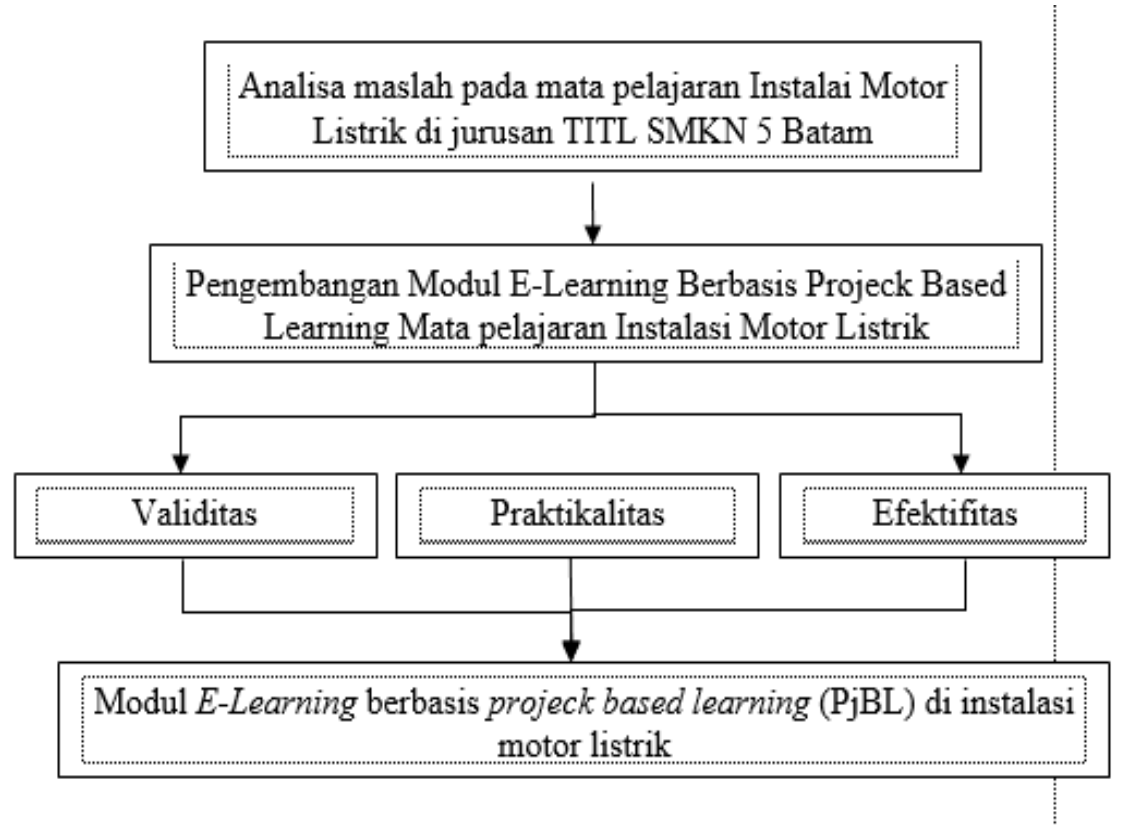

Figure 2. Conceptual Framework

The 4D model has the advantage of being more appropriate to be used as a basis for developing a learning device rather than for developing a learning system. Module development of e-learning -based project-based learning use 4D development. This development model developed by S. Thiagar Ajan, Dorothy S. Semmel, and Melvyn I. Semmel (1974: 5). The Four-D development model consists of 4 main stages: Define, Design, Develop, and Disseminate. The 4D development model was chosen because it has a simple procedure, has a systematic procedure, adapted to the steps of development research to be carried out, and in its development involves expert judgment so that before testing, the media developed have been revised based on the assessment, advice and expert input. 


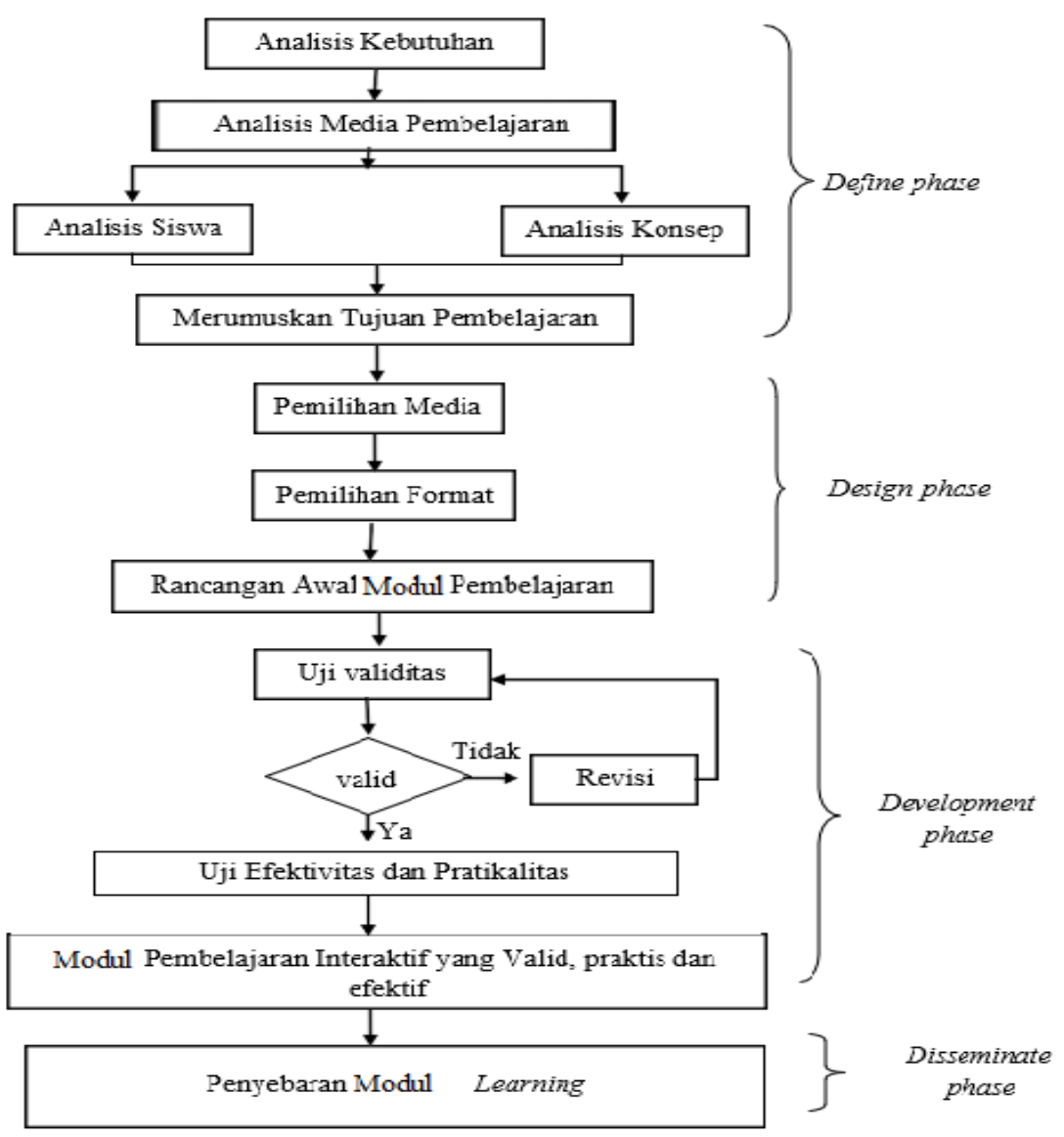

Gambar 3.Prosedur Pengembangan Model 4-D

The determination phase (define) is the initial stage of researching to establish and define the terms of learning. In the design phase or designing the first thing to do is to design e-learning modules based on project-based learning on the subjects of Electric Motor Installation. Planning is carried out to determine the main material contained in this material that is by making an initial design of the media, this concept is developed. In this stage is the stage of producing a learning media which is stated in three steps, namely validity, practicality, and effectiveness. The final goal of making this media is to produce an e-learning learning module based on project-based learning that has been improved by the validators and through trial data. After the development phase carried out the next stage is the deployment phase of designing e-learning modules based on project-based learning that has been validated by the validator and tested on students. The development phase is carried out by disseminating learning media to teachers and students by giving responses in the form of a questionnaire to the learning media.

\section{Results and Discussion}

\section{Results}

The initial appearance of the development of this module is as follows.

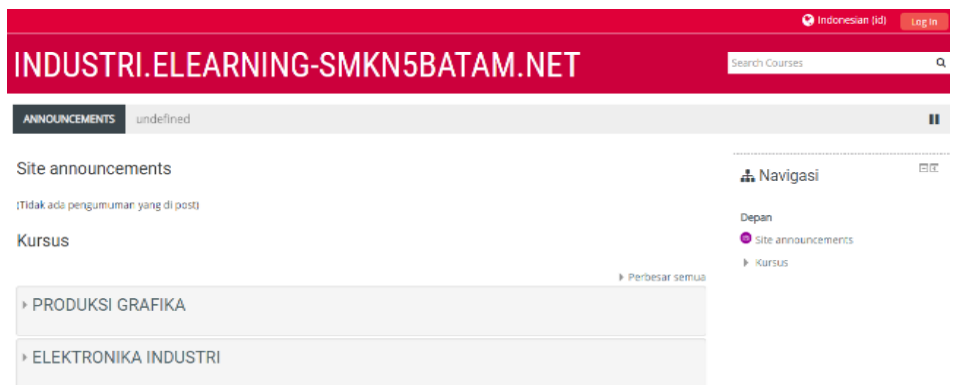

Figure 4. Initial display of the E-learning module 


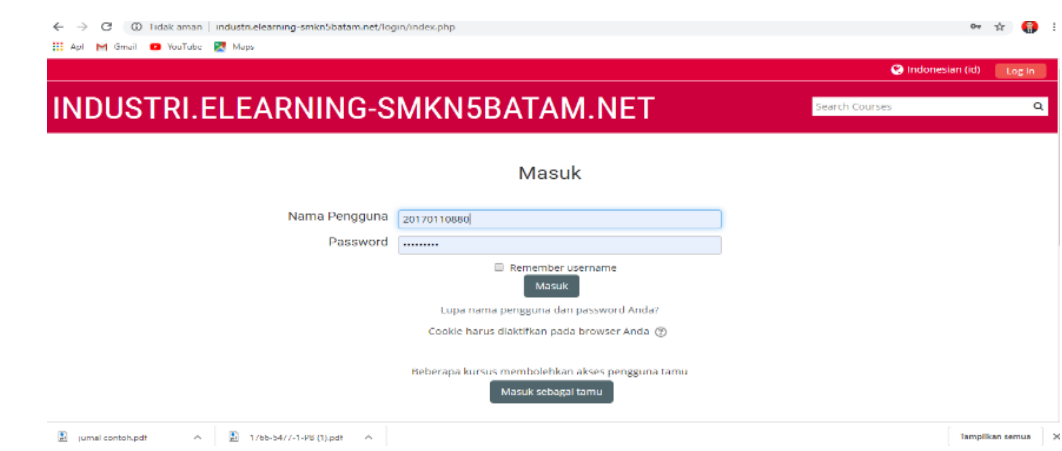

Figure 5. Display Login E-learning

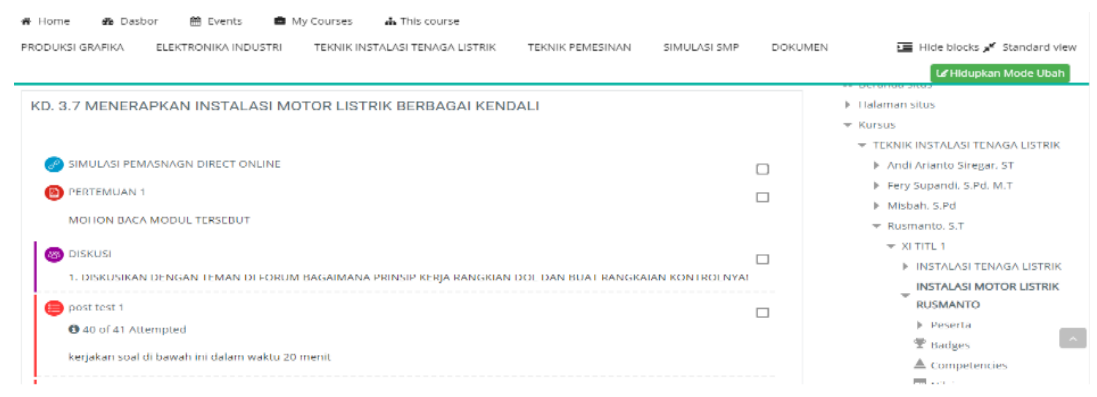

Figure 6. Displaying the E-learning Module

Media validation E-learning module

The validation score of the product design produced. The results of the validation recapitulation summarized from the aspects of the E-learning learning module which are assessed as seen in Table 2.

Table 2. Results of Validation of Project-Based Learning E-Learning Modules

\begin{tabular}{clcc}
\hline No & \multicolumn{1}{c}{ Rating Items } & V & Information \\
\hline Didactic Requirements & 0.85 & Valid \\
$\mathbf{1}$ & The learning module is compatible with basic competencies & 0.9 & Valid \\
$\mathbf{2}$ & Material learning modules following basic competencies & 0.9 & Valid \\
$\mathbf{3}$ & The learning module has examples and assignments accordingly & Valid \\
$\mathbf{4}$ & The learning module is compatible with the characteristics of students & 0.85 & Valid \\
$\mathbf{5}$ & The learning module can direct students in the learning process & 0.8 & Valid \\
$\mathbf{6}$ & The learning module can stimulate student interest and attention & 0.95 & Valid \\
Average & $\mathbf{0 . 8 7 5}$ & Valid \\
Construction Aspects & 0.85 & Valid \\
$\mathbf{1}$ & The language used in the learning module is appropriate & 0.75 & Valid \\
$\mathbf{2}$ & The learning module has consistency in the arrangement of words & 0.85 & Valid \\
$\mathbf{3}$ & The learning module writing has the consistency & 0.95 & Valid \\
$\mathbf{4}$ & The language used in the learning module is easy to understand & 0.8 & Valid \\
$\mathbf{5}$ & The learning modules are following the student's ability to use & 0.9 & Valid \\
$\mathbf{6}$ & Learning module can facilitate students to learn independently & 0.7 & Valid \\
$\mathbf{7}$ & The display in the learning module makes it easy for students to use it & 0.7 & Valid \\
$\mathbf{8}$ & The learning module has the appropriate color display & $\mathbf{0 . 8 1 3}$ & \\
$\mathbf{A v e r a g e}$ & & 0.9 & Valid \\
Technical Note & 0.7 & Valid \\
$\mathbf{1}$ & The learning module has clear icons and menus & 0.85 & Valid \\
$\mathbf{2}$ & Selection of the right type and size of the font & Valid \\
$\mathbf{3}$ & Learning modules have ease in use &
\end{tabular}


5 Choosing the appropriate background and writing colors

6 Display interesting learning modules Average

$\begin{array}{cc}0.7 & \text { Valid } \\ 0.85 & \text { Valid } \\ \mathbf{0 . 8} & \text { Valid }\end{array}$

The results of the validation of the media experts on the E-learning Module with the validity data analysis of the E-learning Module which is used as a medium of learning in motor installations can be seen that the average of didactic requirements was 0.87 with a valid category, the construction aspect was 0.81 with a valid category, and a technical requirement was 0.80 with a valid category.

Table 3. Validation of media experts

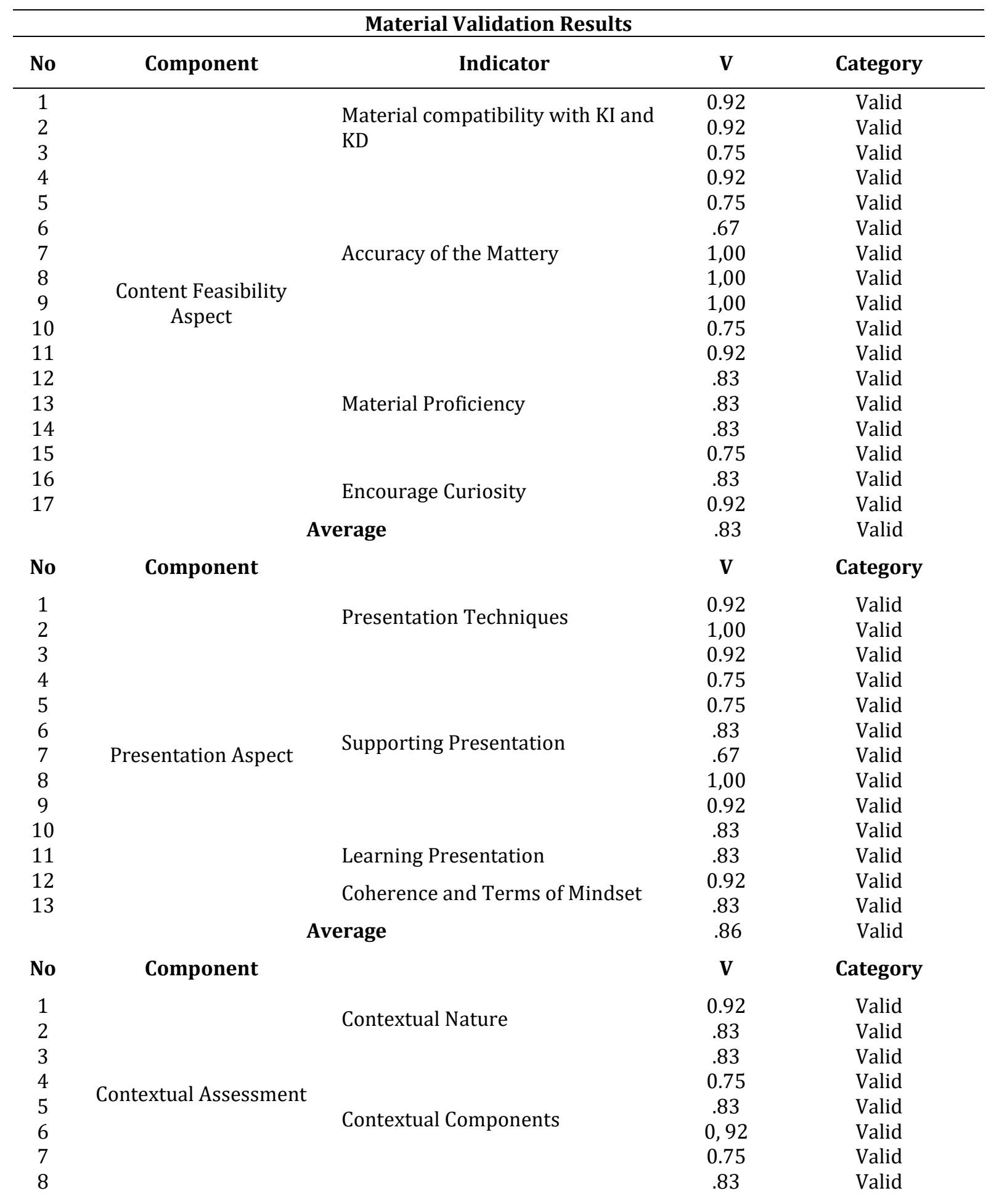


9

$\begin{array}{lcc} & .67 & \text { Valid } \\ \text { Average } & 0.815 & \text { Valid }\end{array}$

The results of the validation of the media experts on the E-learning Module with the validity data analysis of the E-learning Module that is used as a learning media in motor installations can be seen that the average of the content eligibility aspect was 0.83 , the presentation eligibility aspect was 0.86 and the conceptual aspect was 0.81 .

Table 4. Validation of experts discussed

\begin{tabular}{|c|c|c|c|c|}
\hline \multicolumn{5}{|c|}{ Product Validation Results } \\
\hline No & Component & $\begin{array}{l}\text { Indicator } \\
\end{array}$ & $\mathbf{V}$ & Category \\
\hline 1 & \multirow{13}{*}{$\begin{array}{l}\text { Aspects of } \\
\text { Language } \\
\text { Feasibility }\end{array}$} & \multirow{3}{*}{ Straightforward } & .83 & Vali d \\
\hline 2 & & & 1 & Valid \\
\hline 3 & & & 1 & Valid \\
\hline 4 & & Informative & .83 & Valid \\
\hline 5 & & \multirow{2}{*}{ Dialogical and Interactive } & 1 & Valid \\
\hline 6 & & & .67 & Valid \\
\hline 7 & & \multirow{2}{*}{$\begin{array}{l}\text { Conformity with the development of } \\
\text { students }\end{array}$} & 1 & Valid \\
\hline 8 & & & 67 & Valid \\
\hline 9 & & \multirow{2}{*}{ Conformity with Language Rules } & .83 & Valid \\
\hline 10 & & & .83 & Valid \\
\hline 11 & & \multirow{3}{*}{ Use terms, symbols, or icons. } & .83 & Valid \\
\hline 12 & & & .83 & Valid \\
\hline Average & & & .83 & Valid \\
\hline
\end{tabular}

The results of the validation of linguists on the E-learning Module with the validity data analysis of the E-learning Module which used as a learning media in the installation of authorization can be seen that the average aspect of Language eligibility was 0.83. Practicality based on Teacher Response Practicality test data obtained from filling out the practical questionnaire using the E-learning Module as learning media by the teacher. The practical data was taken through a questionnaire filled out by subject teachers.

Table 5. Practicality of Teachers

\begin{tabular}{|c|c|c|c|c|c|c|c|c|}
\hline \multirow{2}{*}{ No } & \multirow{2}{*}{ Rating Item } & \multicolumn{3}{|c|}{ Score } & \multirow{2}{*}{ amount } & \multirow{2}{*}{ Percentage } & \multirow{2}{*}{ Average } & \multirow{2}{*}{ Category } \\
\hline & & G1 & G2 & G3 & & & & \\
\hline 1 & $\begin{array}{l}\text { The e-learning module used is } \\
\text { following the wishes of the } \\
\text { user }\end{array}$ & 4 & 4 & 5 & 13 & 86.67 & & \\
\hline 2 & $\begin{array}{l}\text { The use of E-learning } \\
\text { Modules can generate } \\
\text { student interest in learning }\end{array}$ & 4 & 4 & 5 & 13 & 86.67 & & \\
\hline 3 & $\begin{array}{l}\text { Learning to use this } E \text { - } \\
\text { learning Module can make } \\
\text { students more quickly } \\
\text { understand the material }\end{array}$ & 4 & 4 & 4 & 12 & 80.00 & & \\
\hline 4 & $\begin{array}{l}\text { The use of this E-learning } \\
\text { Module can make learning } \\
\text { more interesting }\end{array}$ & 5 & 5 & 4 & 14 & 93.33 & 88.89 & Valid \\
\hline 5 & $\begin{array}{l}\text { The developed E-learning } \\
\text { Module can be implemented } \\
\text { by the Teacher }\end{array}$ & 5 & 5 & 5 & 15 & 100.00 & & \\
\hline 6 & $\begin{array}{l}\text { E-learning modules that are } \\
\text { designed according to } \\
\text { learning material }\end{array}$ & 4 & 5 & 5 & 14 & 93.33 & & \\
\hline 7 & $\begin{array}{l}\text { Using the } E \text {-learning module } \\
\text { can save time in the }\end{array}$ & 5 & 5 & 4 & 14 & 93.33 & & \\
\hline
\end{tabular}


presentation of the material

Module E-learning that can be

8 developed into a module $E$ -

learning self

This E-learning module can

9 be used because it has clear instructions

$\begin{array}{llll}5 & 4 & 5 & 14\end{array}$

The Project-Based Learning

(PjBL) based e-learning module helps teachers provide learning to students

This E-learning module can

11 help teachers develop student knowledge

The learning process uses a

12 student-centered E-learning Module

$\begin{array}{llll}5 & 4 & 4 & 13\end{array}$

With this E-learning Module

13 as a learning aid media in delivering material

The e-learning module is

14 easily understood by students

15 As motivation of learning for students

$\begin{array}{lllll}4 & 4 & 4 & 12 & 80.00\end{array}$

$\begin{array}{lllll}5 & 4 & 4 & 13 & 86.67\end{array}$

$\begin{array}{lllll}4 & 5 & 5 & 14 & 93.33\end{array}$

The practicality of the E-learning Module which is used as a learning media in subjects of electric motor installation can be seen that the average score was $88.89 \%$ with a very practical category.

Table 6. The results of the practicality of student responses

\begin{tabular}{|c|c|c|c|}
\hline No & Rated aspect & $\mathrm{V}$ & Category \\
\hline \multicolumn{4}{|c|}{ Ease of Use Media Simulator } \\
\hline 1 & $\begin{array}{l}\text { By using this e-learning module I can find out the learning objectives } \\
\text { that I do }\end{array}$ & 92 & $\begin{array}{c}\text { Very } \\
\text { practical }\end{array}$ \\
\hline 2 & I can learn electric motor installation with $e$-learning modules & 92.5 & $\begin{array}{c}\text { Very } \\
\text { practical }\end{array}$ \\
\hline 3 & I can follow the stages of learning in the e-learning module & 86.5 & $\begin{array}{c}\text { Very } \\
\text { practical }\end{array}$ \\
\hline 4 & I'm easy to use e-learning module & 90.5 & $\begin{array}{c}\text { Very } \\
\text { practical }\end{array}$ \\
\hline 5 & $\begin{array}{l}\text { I can understand how the electric motor works from the e-learning } \\
\text { module }\end{array}$ & 95.5 & $\begin{array}{l}\text { Very } \\
\text { practical }\end{array}$ \\
\hline 6 & I can follow the instructions in the e-learning module & 87.5 & $\begin{array}{c}\text { Very } \\
\text { practical }\end{array}$ \\
\hline 7 & $\begin{array}{l}\text { This e-learning module motivated me to learn about installing an } \\
\text { electric motor }\end{array}$ & 92.5 & $\begin{array}{l}\text { Very } \\
\text { practical }\end{array}$ \\
\hline 8 & $\begin{array}{l}\text { This e-learning module interests me to learn about electric motor } \\
\text { control }\end{array}$ & 90 & $\begin{array}{c}\text { Very } \\
\text { practical }\end{array}$ \\
\hline 9 & $\begin{array}{l}\text { Improve my ability to do theory and how to work on the installation } \\
\text { and control of electric motors }\end{array}$ & 93 & $\begin{array}{l}\text { Very } \\
\text { practical }\end{array}$ \\
\hline 10 & My understanding of the learning process increases & 88.5 & $\begin{array}{c}\text { Very } \\
\text { practical }\end{array}$ \\
\hline 11 & I understood the material clearly & 88 & $\begin{array}{c}\text { Very } \\
\text { practical }\end{array}$ \\
\hline Ave & & 91.58 & $\begin{array}{c}\text { Very } \\
\text { practical }\end{array}$ \\
\hline
\end{tabular}


I didn't need a long time to learn about the installation and control of

12 the motor with the e-learning module because it was equipped with a simulation video

13 The time spent is quite efficient

This E-Learning Module helped me to make it easier to understand the electric motor installation material

15 This E-Learning Module can facilitate me to study independently

\section{Average}

Media Attraction

16 The language used in the E-Learning Module is easy to understand

17 The information contained in the E-Learning Module is clear

18 It's been good is the development of E-Learning Module

19 The color combination of the E-Learning Module is good

20 Do you agree with E-Learning Module that this new

$\begin{array}{cc}88 & \text { Very } \\ & \text { practical } \\ 91 & \text { Very } \\ & \text { practical } \\ & \text { Very } \\ 93 & \text { Practical } \\ & \text { Very } \\ 86.5 & \text { practical } \\ & \text { Very } \\ 90 & \text { practical }\end{array}$

88.5

89.5

89

89.5

94.67

92.93
Very
practical

Very

practical

Very

practical

Very

practical

Very

practical

Very

practical

The practicality of using the E-learning Module as a learning media, it can be seen that the average score of the ease of use of the media simulator was $91.58 \%$ with "very practical" category, it is seen from the time used in the implementation that the average score was $90.00 \%$ with "very practical" category, and seen from the appeal of the media that the average score was $92.93 \%$ with "very practical" category.

The effectiveness of using the E-learning Module as a learning media in the installation of electric motors obtained from the achievement of student learning outcomes after using this e-learning module. Student learning outcomes compared before using this e-learning module as learning (pre-test). Testing the validity of the trial instrument carried out by conducting a test on electrical power installation engineering students (outside the sample), the number of trials was 44 students. After testing the validity of the item items out of 45 questions given, there were 20 valid items: $1,4,6,7,9,12,14,16,20,22,26,29$, $31,32,34,39,40,42,44$, and 45 . While the 25 items that are not valid: $2,3,5,6,8,10,11,13,15,17,18$, $21,23,24,25,27,28,30,33,35,36,37,38,41,43$, and. Data from the results of testing the validity of the questions. Reliability test measured whether the test can be trusted, the results of the calculation of the reliability of the questions were known that all reliable questions using Microsoft Excel 2007 and more clearly can be seen in the reliability obtained by the score was 0.87 . The results compared with the $r$ table, from the table the score was 0.88 in the range of $0.88 \leq r \leq 1.00$. The results of the analysis and based on interpretation of the $r$ score, it can be seen that the test has a very high level of test reliability 0.87 with the results of student learning through the e-learning module developed, after pretest and posttest using 20 multiple choice questions items, Test the significance of the difference was done using Gain Score analysis which consists of two types, namely: Pretest (initial test) and Posttest (final test) and the average results of the overall Gain Score of students.

Table 7. Pretest, Posttest and Gain Score statistics

\begin{tabular}{cccccc}
\hline Score & $\mathbf{N}$ & $\boldsymbol{X}_{\min }$ & $\boldsymbol{X}_{\max }$ & Elementary school \\
\hline Pretest & 40 & 8 & 16 & 60 & 2.37 \\
Posttest & 40 & 11 & 19 & 80 & 2.09 \\
N-Gain & 40 & .17 & .10 & 0.52 & .16 \\
& \multicolumn{6}{c}{ Comparison of\% Posttest and Pretest $=\mathbf{2 0 \%}$} \\
\hline
\end{tabular}


Based on table 4. above, obtained an average pretest score of 60.63 , an average posttest score of 80.25 , and an average $\mathrm{N}$ - gain of all students was 0.52 . the pretest standard deviation 2.37 , the standard deviation of the posttest was 2.09 and the standard deviation seen from the N-gain was 0.16 , it can be concluded that there are differences between the pretest and posttest learning outcomes.

\section{Discussion}

Based on the results of research on the development of e-learning modules based on project-based learning that has been done, it can be concluded that the development of e-learning modules as learning media can be said to have been successfully developed so that the e-learning module has reached the validity, practicality and test stages. effectiveness. Validator data validity analysis results consisted of four lecturers, two from Riau Islands University (UNRIKA), two from the College of Information Management and Computing (STIMK GICI), one Head of school, the validator e-learning module gave a score was 0.81 for the aspects of the requirements didactic, for the construction aspect with the score was 0.87 , while for the technical requirements with the score was 0.80 that it can be concluded that the overall score of the elearning module received an average of 0.82 with a valid category.

The results of the validation data analysis of the material experts of the E-learning Module with the analysis of the validity data of the E-learning Module which is used as a learning media on motor installations can be seen that the average of the content eligibility aspects was 0.83 , the feasibility aspect of the presentation was 0.86 and conceptual aspects were 0.81 . Results of the assessment of each aspect of a given indicator can be taken validator average overall validity of the tool can be concluded that the Elearning module developed in the "Valid" category. The results of the validation of linguists on the Elearning Module with the validity data analysis of the E-learning Module used as a learning module in motor installations can be seen that the average aspect of Language eligibility was 0.83 Assessment results from each aspect of the indicators provided validator can be taken the average overall validity of the tool can be collected that the E-learning Module that was developed meant the "Valid" category.

The results of the data analysis seen from the practicality based on the response of 3 (three) teachers get an average score was $87.56 \%$ with a very practical category and the results of the data analysis seen from the practicality based on the students' responses are known to average scores: hopefully, the use of media simulator was $91,58 \%$ with a very practical category, the time spent in the implementation was 90.00 with a very practical category and the attractiveness of the media was 92.93 with a very practical category. So, when viewed from the total results the overall average score was $91.50 \%$ with a very practical category.

This is in line with the results of research conducted by Yulianti et al., (2014) which showed that the results of data analysis are seen from the effectiveness test based on the pretest and posttest. It can be seen from the average score of pretest score was $55.83 \%$ and the average posttest score was $72.50 \%$. If the average $\mathrm{N}$-gain of overall students was 0.37 . The validation results of the three validators obtained an assessment of the module with a total score was $403(91,59 \%)$ and included in excellent category and can be used without revision. The implementation of learning during four meetings obtained an average score was 110.5 (92.08\%) from two observers included in the excellent category. Student responses to the developed products obtained criteria strongly agree $42.17 \%$ and agree $53.17 \%$ on the attractiveness aspects of the module display, ease of learning, and the usefulness of the module as a learning resource, learning instructions, and can help optimize students' life skills on aspects thinking skills with a total score was 784 included in the very good category, aspects of social skills with a total score was 532 included in the excellent category, and aspects of academic skills with a total score was 204 included in the very good category.

Wahyu Islamul Hayati, Sugeng Utaya (2016) also found that first, the level of effectiveness of Project-Based Learning Student Worksheets in fostering students' critical thinking skills after the teaching of $58 \%$ had good critical thinking qualifications. Secondly, the students' responses to the Project-Based Learning Worksheet based on $78.68 \%$ have decent qualifications, meaning that the products produced can be accepted by students and learning activities can be carried out well. Ilmas Barlenti, M. Hasan (2017) found that the application of PjBL based LKS can improve students' understanding of concepts in colloidal material, increasing each indicator with a low category. T-test results showed differences before and after the use of PjBL-based worksheets seen from the students' pretest and posttest scores. Student responses to the application of PjBL-based worksheets on colloid material received positive responses from students. The researcher suggests that the application of PjBL based LKS can be used as an alternative that can be applied to make students study independently and solve problems faced in their environment.

Sunarya et al., (2016) found that the implementation of e-module digital simulation based on project-based learning had been stated as good. This can be seen from the average percentage based on the results of the tests conducted. In general, students look enthusiastic and actively involved during the 
learning process. Based on students' responses to the development of e-modules based on project-based learning in digital simulation subjects at SMK Negeri 2 Singaraja, the average percentage of all subjects was $90.6 \%$. If converted into a conversion table included in the category of "very good".

This is also in line with Winaya et al., (2017) who explained that the results of the design and implementation of e-modules have been developed on web programming subjects for grade X students in Computer Engineering and networking using the Project-Based Learning model in SMK Negeri 3 Singaraja was declared successful because it was based on 1) subject matter expert test, 2) learning design test, and 3) learning media test that had been conducted. The designs previously carried out are following the emodules developed, including the design of features used such as Page, Forum, Assignments, Files, and Quizzes. Based on students' responses to the e-module web-based subjects of Project-Based Learning for class X Competency of Computer and Network Engineering Skills at SMK Negeri 3 Singaraja, the average student response was $82.6 \%$ in terms of appropriateness of appearance, ease of use of e-modules, motivation towards students and content. If converted into a conversion table the achievement level is included in either category. Whereas for teacher responses to e-modules, an average response was $94 \%$ obtained in terms of ease of use of e-modules, student enthusiasm, and teaching using e-modules. If converted into a conversion table the achievement level was included in the excellent category.

\section{Conclusion}

Based on the research results of the development of e-learning modules based on project-based learning that has been done, it can be concluded that the development of e-learning modules as learning media can be said to have been successfully developed so that the e-learning module has passed the stages of validity, practicality, and effectiveness. Validity analysis results consisted of four lecturers, two from Riau Islands University (UNRIKA), two from the College of Information and Computer Management (STIMK GICI), one Principal, the e-learning module validator gave 0.81 for aspects of didactic requirements, for the construction aspect 0.87 , while for the technical requirements 0.80 . It can be concluded that the overall score of the e-learning module was 0.82 with a valid category.

Based on the results of the e-learning module development that has been done with valid results after going through the validation stage, the results of the validity data analysis with the overall score of the simulator was 0.82 with a valid category, the validity data of the E-learning Module used as a medium learning in motor installations can be seen that the average of the content eligibility aspect was 0.83 , the feasibility aspect was 0.86 , and the conceptual aspect was 0.81 . learning modules in motor installations can be seen that the average aspect of the language feasibility was 0.83 practicality based on the response of 3 (three) teachers get an average rate $87.56 \%$ with a very practical category of effectiveness test based on pretest and posttest. It can be seen from the average score of pretest score was $55.83 \%$ and the average posttest score was $72.50 \%$. If the overall $\mathrm{N}$-gain of students was 0.37 . Based on the findings of the study it can be recommended that the E-learning module is an alternative teaching material in learning that can be used in learning on electric motorization (IML) subjects.

\section{References}

A.M. Sardiman. 2012. Interaksi dan Motivasi Belajar Mengajar, Jakarta: Rajawali Pers.

A. Pribadi, Benny. 2009. Model Desain Sistem Pembelajaran. Jakarta: PT Dian Rakyat.

Abdul Majid. 2006. Perencanaan Pembelajaran. Bandung: PT Remaja Rosdakarya.

Abdul Majid dan Chaerul Rochman. 2014. Pendekatan Ilmiah dalam Implementasi Kuirikulum 2013. Bandung: PT Remaja Rosdakarya.

Abidin, Yunus. 2013. Pembelajaran Bahasa Berbasis Pendidikan Karakter. Bandung: Refika Aditama.

Acar, O. \& Patton, B.R. 2012. Argumentation and Formal Reasoning Skills in An Argumentation-Based Guided Inquiry Course. Procedia-Social and Behavioral Sciences Journal, 46 2012, page. 47564760 .

Alwi.2002. Kamus Besar Bahasa Indonesia. Jakarta: Balai Pustaka.

Akaid shoimin. 2014. Model Pembelajaran Inovatif Dalam Kurikulum 2013. Yokyakarta: AR-ruz media. 
Anwar Iful, 2015. "Pengaruh Harga Dan Kualitas Produk Terhadap Keputusan Pembelian Konsumen". Jurnal Ilmu Dan Riset Manajemen, 4(12).

Arief Sadiman. 2002. Media Pembelajaran dan Proses Belajar Mengajar, Pengertian Pengembangan dan Pemanfaatannya, Jakarta: Raja Grafindo Persada.

Ariesto H. Sutopo. 2012. Teknologi Informasi dan Komunikasi dalam Pendidikan. Yogyakarta: Graha Ilmu.

Arsyad, Azhar. 2002. Media Pembelajaran, edisi 1. Jakarta: PT. Raja Grafindo Persada.

Adianto, Ridwan, 2009, Penggunaan Media Pembelajaran Berbasis Teknologi dan Komunikasi dengan Pemanfaatan Software Delphi untuk Meningkatkan Minat Belajar Siswa, (Skripsi), Surakarta, FKIP UMS

Arikunto, Suharsimi. 2012. Prosedur Penelitian Suatu Pendekatan Praktek. Jakarta: Rineka Cipta.

Daryanto. 2016. Media Pembelajaran. Yogyakarta: Gava Media.

Dessler, Gary. 2015. Manajemen Sumber Daya Manusia. Jakarta: Salemba Empat.

Ditjen Depdiknas. 2008, Supervisi Akademik, Jakarta: Ditjen PMPTK.

Fauzan, A., Plomp, T., \& Gravemeijer, K. 2013. The development of an rme-based geometry course for Indonesian primary schools. In T. Plomp, \& N. Nieveen (Eds.), Educational design research - Part B: Illustrative cases (pp. 159-178). Enschede, the Netherlands: SLO

Latuheru, John D. 1988. Media Pembelajaran Dalam Proses Belajar-Mengajar Masa Kini. Jakarta: Departemen Pendidikan dan Kebudayaan.

Mudlofir, Ali \& Rusydiyah, Evi Fatimatur. 2015. Desain Pembelajaran Inovatif dari Teori ke Praktik. Jakarta: PT Raja Grafindo Persada.

Nurrohman Endrik. et.al. 2017. Keanekaragaman Makrofauna Tanah di Kawasan Perkebunan Coklat (Theobroma cacao L) Sebagai Bioindikator Kesuburan Tanah dan Sumber Belajar Biologi. Jurnal Pendidikan Biologi Indonesia.1 (2) : 197-208.

Nasution. 2009. Metode Research (Penelitian Ilmiah). Jakarta: Bumi Aksara.

Ningtyas, S. D. Y. 2018. Hubungan Antara Self Control Dengan Internet Addiction Pada Mahasiswa. Educational Psychology Journal. 1, 1, 25-30.

Ngalim Purwanto. 2009. Evaluasi Hasil Belajar. Yogyakarta: Pustaka Pelajar.

Hake, R, R. 1999. Analyzing Change/Gain Scores.AREA-D American Education Research Association's Devision.D, Measurement and Reasearch Methodology

Oktavia, N. 2015. Sistematika Penulisan Karya Ilmiah Ed.1. Yogyakarta: Deepublish

Sungkono. 2003. Pengembangan Dan Pemanfaatan Bahan Ajar Modul Dalam Proses Pembelajaran. Makalah Yogyakarta: FIP UNY

Sudjana, Nana dan Ahmad Rivai. 2007. Media Pengajaran. Bandung: Sinar Baru Algensindo

Sugiyono 2015. Metode Penelitian Kombinasi (Mix Methods). Bandung: Alfabeta.

Sugiyono 2019. Metode Penelitian Kualitatif: Untuk penelitian yang bersifat: eksploratif, enterpretif, interaktif, dan konstruktif. Bandung: Alfabeta. 
Thiagarajan Sivasailam, Dorothy S. Semmel dan Melvyn I. Semmel. 1974. Instructional Development for Training Teachers of Exceptional Children. Bloomington: Indiana University.

Trianto. 2014. Model Pembelajaran Terpadu: Konsep, Strategi, dan Implementasinya dalam Kurikulum Tingkat Satuan Pendidikan (KTSP). Jakarta. Bumi Aksara.

Warsito, H. Rindiani. dan Nurdiansyah, F. 2015. Ilmu Bahan Makanan Dasar. Nuha Medica. Yogyakarta.

Warsono dan Hariyanto. 2012. Pembelajaran Aktif Teori dan Asesmen. Bandung: PT Remaja Rosdakarya. 